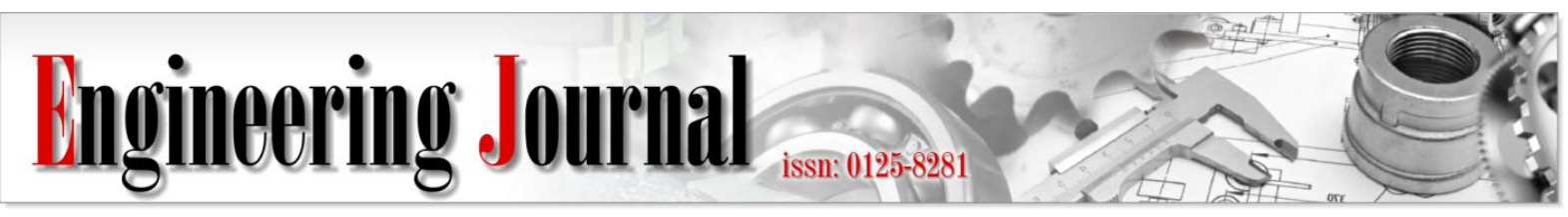

Article

\title{
Flow Budget Change of Groundwater System under Climate Change in the Upper Central Plain, Thailand
}

\author{
Chokchai Suthidhummajit ${ }^{\mathrm{a},}$ and Sucharit Koontanakulvong \\ Department of Water Resources Engineering, Faculty of Engineering, Chulalongkorn University, Bangkok, \\ Thailand \\ *E-mail: chokchai.s@chula.ac.th (Corresponding author)
}

\begin{abstract}
The Upper Central Plain of Thailand, where farmers depended on both surface water and groundwater. Water allocated from the Bhumibol and Sirikit Dams are limited and caused water shortage in the dry years. Most farmers turn to use groundwater to supplement irrigation water in the dry years. This study aims to understand the flow budget change of groundwater under climate change scenario. The conjunctive use ratio of surfaceas well as groundwater were investigated by field surveys and groundwater flow modeling, using the MODFLOW model to simulate the groundwater movement over the 10 years . The study used the bias-corrected MRI-GCM data to project the future climate conditions (during 2015 -2029 and 2075-2089) and assess the impact on flow budget change of groundwater system. The conjunctive use ratio were analyzed from surface water use and flow budget of groundwater system in term of water demand, rainfall, reservoir storage, groundwater recharge, groundwater storage, groundwater pumping. The study shows the flow budget-change and conjunctive use ratio of each season and water year in the past and in the future under climate change scenarios.
\end{abstract}

Keywords Flow budget change, climate change, conjunctive use, Upper Central Plain, Thailand.

ENGINEERING JOURNAL Volume 22 Issue 1

Received 14 September 2017

Accepted 28 October 2017

Published 31 January 2018

Online at http://www.engj.org/

DOI:10.4186/ej.2018.22.1.289 


\section{Introduction}

The Upper Central Plain of Thailand, which means Northern part of Chao Phraya Plain, covers the areas of Uttaradit, Sukhothai, Pitsanilok, Kampangphet, Pichit, and Nakornsawan Provinces, where farmers depended on both surface water and groundwater. Water allocated from the Bhumibol and Sirikit Dams are limited and caused water shortage in the dry years. Most farmers turn to use groundwater to supplement irrigation water in the dry years. This also caused groundwater drawdown and make farmers to dig deeper (shallow) wells which made more cost for agriculture [1]. In this area, it is difficult for the downstream area to receive irrigation water through canal, thus farmers dig their own groundwater wells in their paddy fields and pumped groundwater individually to compensate surface water shortages

The focus of the paper is to understand the flow budget change of groundwater at present and climate change impacts on flow budget of groundwater system and sw-gw conjunctive use ratio in the future in the study area.

\section{Study Area}

Upper Central Plain is in the Northern part of Chao Phraya Plain covering the areas of Uttaradit, Sukhothai, Pitsanulok, Kampangphet, Pichit, and Nakornsawan Provinces. Total area is 47,986 square kilometers or 29,991,699 rais. Average height is approximately 40-60 meters above mean sea level. The areas consist of sediments which were changed from erosion and decay of rock, then accumulate and generate as plain, terrace, and swamp. Fig. 1 shows topography and boundary.

The climate of the Upper Central Plain is under the influences of monsoon winds i.e. southwest and northeast monsoon. From the meteorological point of view the climate of Upper Central Plain can be divided into three seasons that are summer (mid-February to mid-May), rainy season (mid-May to October), and winter (November begin to mid-February). The study area is composed of 5 basins that are Lower Ping basin, Lower Yom basin, Lower Nan basin, Upper Sa-Grae-Grang basin, and Upper Chao Phraya basin, as shown in Fig. 1.

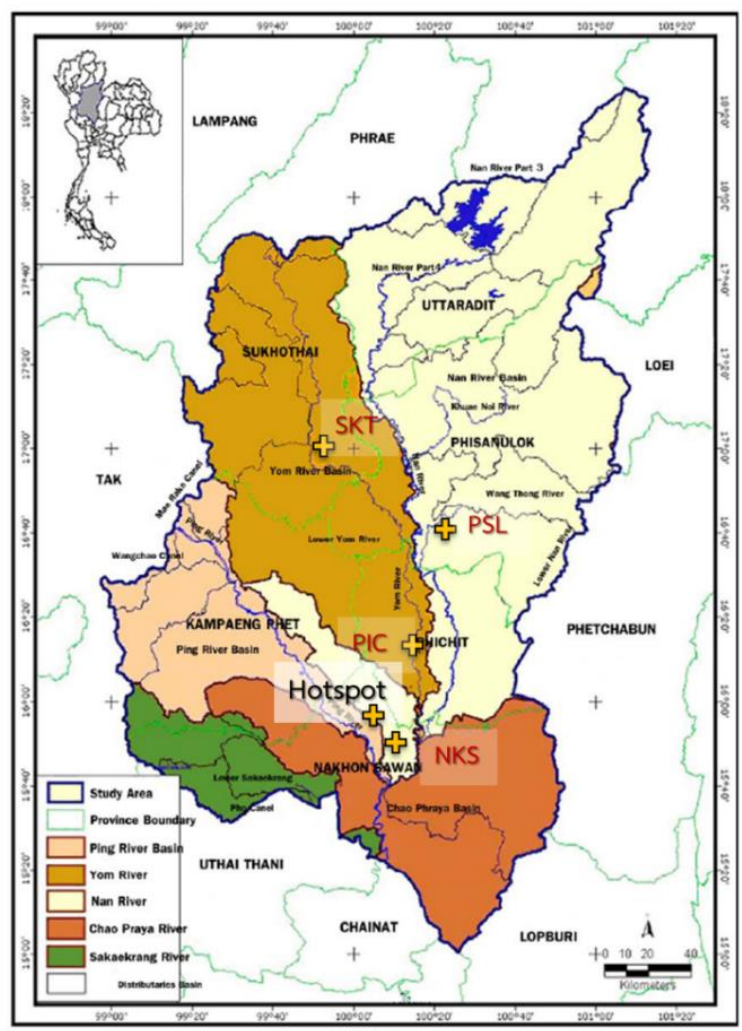

Fig. 1. Upper Central Plain Basin. 
The main rivers in the study areas are the Yom and the Nan Rivers which flow parallel from North to South and join at Ban Gei Chai, Amphor Chumsang, Nakornsawan Province. In addition, there is the Ping River which flows from west side and joins with the Yom and the Nan River at Amphor Paknampho, Nakornsawan Province. They become the Chao Phraya River, which continuously flow to the Central Plain.

From daily and monthly rainfall data of rainfall stations (68 stations) that collected during 1974 to 2003, the amount of rainfall in the Upper Central Plain is between 900 to 1,450 mm/year. From 52 station runoff data of Royal Irrigation Department that collected during 1994 to 2003, the total runoff 15,481.9 million cubic meters per year, divided into rainy season 13,625 million cubic meters, $88 \%$ of total runoff, and dry season $1,856.9$ million cubic meters, $12 \%$ of total runoff.

\section{Methodology}

To understand flow budget change and the conjunctive use ratio, there are two steps in this study, i.e., first step is to modify the groundwater model [2] by including the effect of the future climate in term of groundwater recharge rate from climate data and seven groups of soil data series, and to see the flow budget and conjunctive use patterns in the present period, second step is to simulate the impact towards conjunctive use pattern and flow budget by using the recharge relationship derived from the part 1 and the projected bias corrected the MRI GCMs climate data [3] in two future time frames, i.e., near future (2015-2029) and far future (2075-2089) periods. A linear regression method was applied to develop relationship between recharge flux and value of monthly precipitation minus evapotranspiration via groundwater model recalibration. The improved groundwater model (MODFLOW) was applied to assess the impact of climate change on flow budget (groundwater recharge and ground water table) in the study area and to find the impact on flow budget and conjunctive use ratio.

\section{Groundwater model}

Groundwater model using in this study is MODFLOW (the USGS's three-dimensional (3D) finite-difference groundwater model). MODFLOW is considered an international standard for simulating and predicting groundwater conditions and groundwater/surface-water interactions. The three-dimensional movement of ground water of constant density through porous earth material may be described by the partial-differential equation

$$
\frac{\partial}{\partial x}\left[K_{x x} \frac{\partial h}{\partial x}\right]+\frac{\partial}{\partial y}\left[K_{y y} \frac{\partial h}{\partial y}\right]+\frac{\partial}{\partial z}\left[K_{z z} \frac{\partial h}{\partial z}\right]+W=S_{s} \frac{\partial h}{\partial t}
$$

where

$K_{x x}, K_{y y}$ and $K_{z z}$ are the values of hydraulic conductivity along the $x, y$, and $z$ coordinate axes (space function);

$\mathrm{h}$ is the potentiometric head (hydraulic head);

$\mathrm{W}$ is a volumetric flux per unit volume representing sources and/or sinks of water, where negative values are water extractions, and positive values are injections. It may be a function of space and time (i.e. $\mathrm{W}=$ $\mathrm{W}(\mathrm{x}, \mathrm{y}, \mathrm{z}, \mathrm{t}))$;

$\mathrm{S}_{\mathrm{s}}$ is the specific storage of the porous material (space function);

$\mathrm{t}$ is time.

\section{Recharge equation}

From the water budget analysis in the soil layer, the simple water budget is

$$
\mathrm{P}=\mathrm{ET}+\Delta \mathrm{S}+\mathrm{Roff}+\mathrm{D}
$$

where

$\mathrm{P}$ is precipitation;

ET is evapotranspiration;

$\Delta \mathrm{S}$ is change in water storage in soil column;

$\mathrm{R}_{\text {off }}$ is direct surface runoff; and

$\mathrm{D}$ is drainage out of the bottom soil which is equivalent to recharge (R). 
From the above relation, the recharge can be approximated simpler by using following equation [4]:

$$
\mathrm{R}=\mathrm{P}-\mathrm{ET}-\mathrm{Q}_{0}
$$

Equation (4) can be written again as follow:

$$
\mathrm{R} / \mathrm{P}=\mathrm{a}_{\mathrm{i}}^{*}(\mathrm{P}-\mathrm{ET}) / \mathrm{P}+\mathrm{b}_{\mathrm{i}}
$$

where

$a_{i}$ and $b_{i}$ are constant and can be found by using goodness fit test for each soil group;

$\mathrm{Q}_{\mathrm{o}}=\mathrm{R}_{\mathrm{off}}=$ runoff outflow (assumed zero in monthly scale);

$P$ is precipitation, and ET is evapotranspiration and can be calculated by equation of temperature (T) [5]:

$$
\mathrm{ET}=\mathrm{c}^{*} \mathrm{~T}+\mathrm{d}
$$

where $\mathrm{c}$ and $\mathrm{d}$ are constants and can be found by using goodness fit test for each month [6].

\section{Recharge function}

The rates of groundwater recharge in each soil group zone from the step above were calculated by the developed relationship [6] between recharge and amount of monthly precipitation minus monthly evapotranspiration per precipitation (Eq. (5)),

\section{Groundwater use}

The total number of shallow wells in the study area in 2003 has been 78,114 with a ratio of agricultural to domestic consumption-well of 1:3 [2] and an average daily domestic consumption of $0.71 \mathrm{~m} 3 /$ well, amounting to a total domestic-consumption from wells of 15 million m3/year in 2003. The major groundwater use in this area is for agriculture. Since the crop pattern is seasonally planed, the agricultural stress- period used in the model is also based on the climatic conditions. Agricultural wells' records often do not exist and the pumping behavior is unknown, for this reason, the investigation results about the actual water use pattern, farmers' behavior and constraints, i.e. harvest terms, groundwater pumping hours, pumping rates, maximum water drawdown, etc., in the Plychumpol irrigation project area in Phitsanulok Province has been used to estimate the groundwater use for agriculture. The major pumping statistics retrieved from the survey which concluded that the average pumping capacity per well is $41 \mathrm{~m} 3 /$ hour, whereas the average pumping rate per well is $79 \mathrm{~m} 3 /$ day inside the irrigation project, and $76 \mathrm{~m} 3 /$ day outside [7] The historical yearly record of the wells in each province during 1993-2003 was converted to a growth rate of the well concentration for the future. As mentioned, besides the seasonally agricultural water use, the latter depends also on the surface water supply available during the time which is linked to the actual storage of two main upstream reservoirs [2], i.e., the Bhumibol and Sirikit reservoirs which provide surface-water and irrigation water to this area. The water demand, the conjunctive use ratio (described by the ratio of groundwater use and surface water use) compared with the water demand and water situation from 19932003 as shown in Table 1. In average, the conjunctive use ratio was $9 \%$ to $25 \%$. In drought year, the conjunctive use ratio was highest (23-25\%) and the lowest was in wet year (9-11\%). 
Table 1. The water demand and the sw-gw conjunctive use ratio in water year during 1993-2003.

\begin{tabular}{ccccccc}
\hline Year & $\begin{array}{c}\text { Water } \\
\text { demand } \\
(\mathrm{MCM})\end{array}$ & $\begin{array}{c}\text { SW-Supply } \\
(\mathrm{MCM})\end{array}$ & $\begin{array}{c}\text { GW-Supply } \\
(\mathrm{MCM})\end{array}$ & $\begin{array}{c}\text { Deficit } \\
(\mathrm{MCM})\end{array}$ & $\begin{array}{c}\text { CJ-ratio } \\
(\%)\end{array}$ & $\begin{array}{c}\text { Water } \\
\text { year }\end{array}$ \\
\hline 1993 & 3,108 & 2,445 & 421 & 241 & 17 & Dry \\
1994 & 3,217 & 2,443 & 551 & 222 & 23 & Drought \\
1995 & 3,020 & 2,575 & 287 & 158 & 11 & Wet \\
1996 & 4,043 & 3,517 & 302 & 224 & 9 & Wet \\
1997 & 3,898 & 3,222 & 524 & 153 & 16 & Normal \\
1998 & 3,290 & 2,457 & 540 & 293 & 22 & Normal \\
1999 & 3,628 & 2,882 & 715 & 31 & 25 & Drought \\
2000 & 3,670 & 3,072 & 560 & 39 & 18 & Normal \\
2001 & 3,843 & 3,074 & 333 & 435 & 11 & Wet \\
2002 & 3,811 & 3,404 & 336 & 71 & 10 & Wet \\
2003 & 4,311 & 3,858 & 336 & 117 & 9 & Wet \\
\hline
\end{tabular}

\section{Results and Discussion}

\subsection{Groundwater Model Calibration}

Groundwater flow model (MODFLOW) was used to simulate groundwater flow conditions in the area during the period 1993-2003. Input data included river water level, observation groundwater level, and well abstraction used from the former project [2]. The layer aquifer conceptual model and model grid design as shown in Fig. 2. In this study, the model was calibrated compared with observation data using recharge equation derived [8]. Model calibration and verification were performed in steady state as well as in transient state. Following the seasonal crop pattern, the seasonal stress period was used in the calibration of two years of recorded historical groundwater levels. Calibration in transient state has been carried out, using the 19932003 historical water levels, whereby groups of specific storage have been calibrated. Results of calibrated model (in Fig. 3) show that simulated values were closer with observed data and the root mean square calibration error is $3.70 \mathrm{~m}$ in steady-state mode and $3.9 \mathrm{~m}$ in transient model.

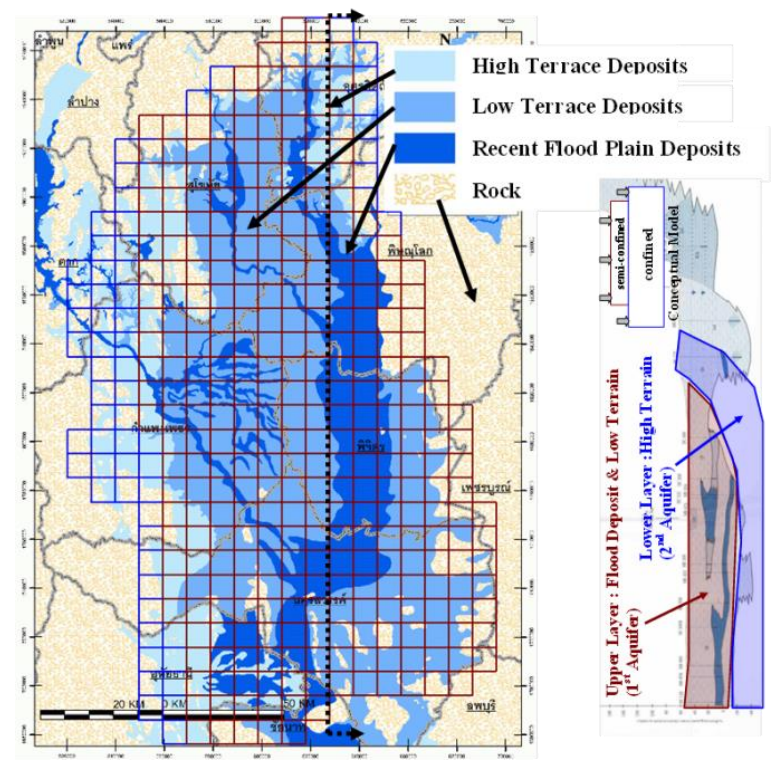

Fig. 2. Layer aquifer's conceptual model and model grid design. 


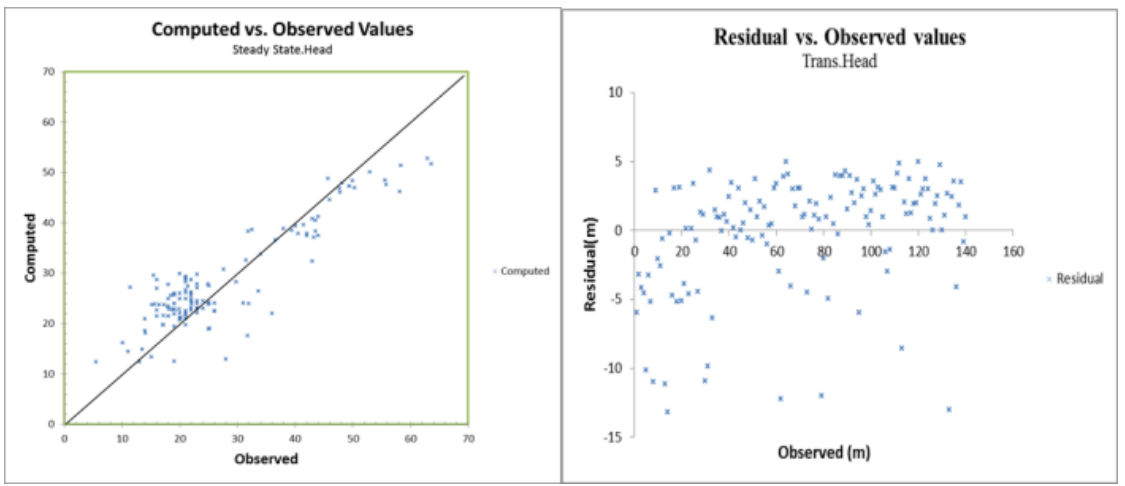

a) steady state

b) transient state

Fig. 3. Computed vs. observed values in steady state and transient state.

\subsection{Flow Budget}

Figure 4 is the groundwater flow budget in dry season when farmers used groundwater. The main outputs are pumping and river discharge. Storage change in $1^{\text {st }}$ layer is minus and needs supply from $2^{\text {nd }}$ layer. In the $1^{\text {st }}$ layer, the average land recharge was small $(25 \mathrm{MCM})$ and was lower than the discharge to the river (-102 MCM). The average groundwater pumpage was $325 \mathrm{MCM}$ which is high and needs to receive water from $2^{\text {nd }}$ layer. For the $2^{\text {nd }}$ layer, the average land recharge was nearly $0 \mathrm{MCM}$. The average groundwater pumpage was $38 \mathrm{MCM}$. The flow in boundary and flow out boundary were $37 \mathrm{MCM}, 27 \mathrm{MCM}$ and $30 \mathrm{MCM}, 1 \mathrm{MCM}$ in $1^{\text {st }}$ layer and $2^{\text {nd }}$ layer, respectively, and the interaction flow between 2 layers was 64 MCM from $2^{\text {nd }}$ layer to 1 st layer.

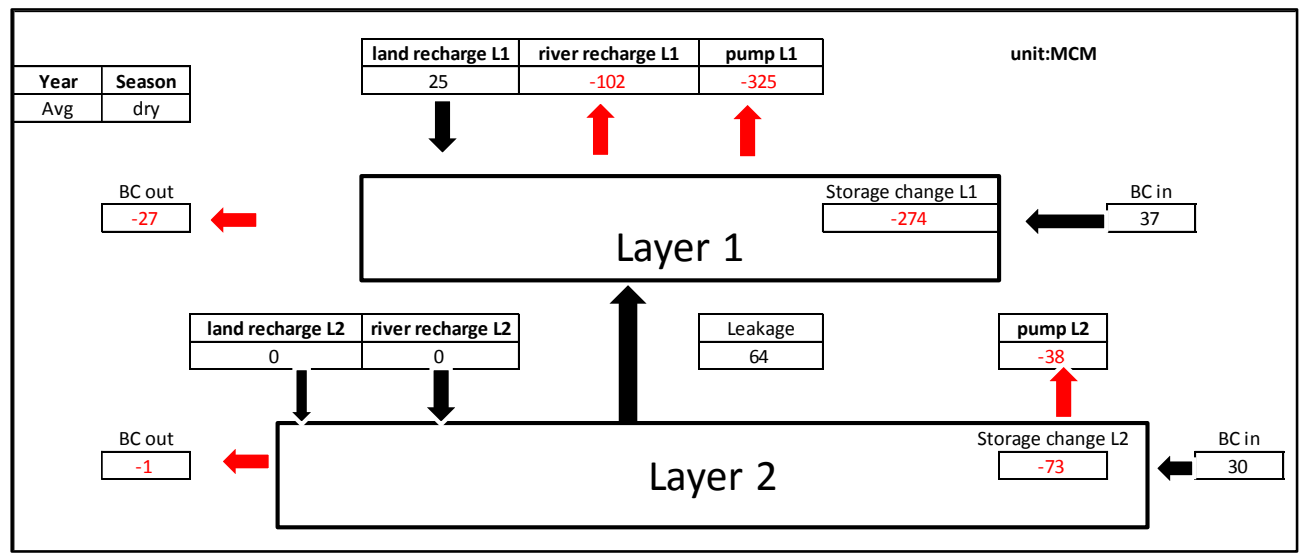

Fig. 4. The flow budget of the groundwater system in dry season.

The $1^{\text {st }}$ aquifer is the main aquifer where farmers pumped water for their paddy field. From the model, the flow budget of groundwater system of $1^{\text {st }}$ layer in seasonal and annual basis are shown in Table 2 and Fig. 5. It can be seen that the main input is from land recharge while the main outputs are pumping and river recharge. The average land recharge was 1.1, 0.137 and $1.237 \mathrm{MCM} /$ season/day in wet season, dry season and annual respectively. The river recharge worked differently from land recharge. It recharged to aquifer in wet season (0.35 MCM/season/day) but it received water from aquifer in dry season (-0.56 $\mathrm{MCM} /$ season/day). The amounts of $0.35,-0.56$ and $-0.21 \mathrm{MCM} /$ season/day were in wet season, dry season and annual respectively. The average groundwater pumpage was high, nearly $1.8 \mathrm{MCM} / \mathrm{season} / \mathrm{day}$ in dry season, hence, the average groundwater storage change decreased to $1.5 \mathrm{MCM} /$ season/day in dry season and this was the reason that the average groundwater level in dry season in this area decreased too. 


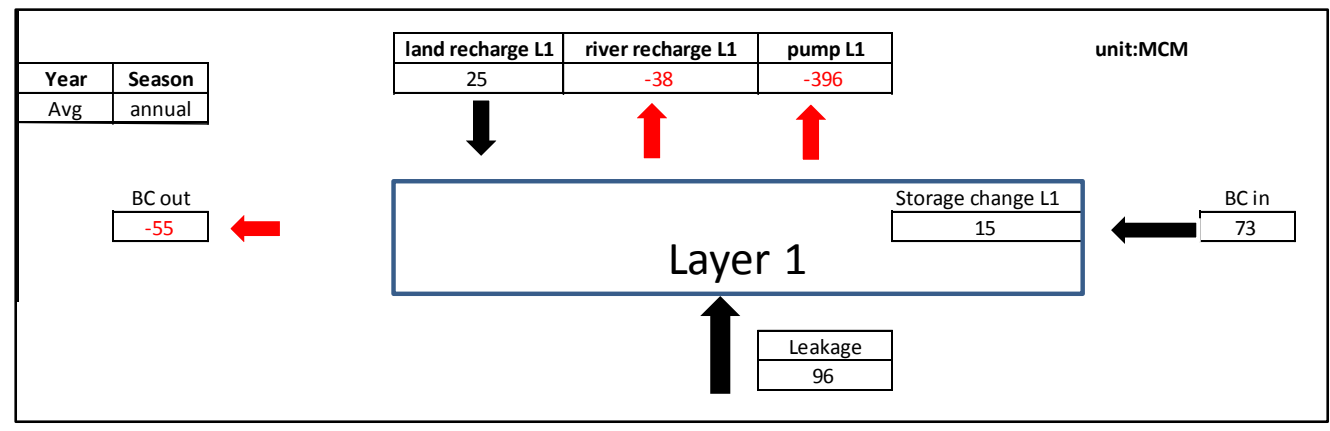

Fig. 5. The annual flow budget of groundwater system (aquifer 1) in the Present period.

Table 2. The seasonal flow budget of groundwater system in the Present period.

\begin{tabular}{lrrr}
\hline Time Period & \multicolumn{3}{c}{ Present(MCM/season/day) } \\
\hline Season & wet & dry & annual \\
\hline River recharge & 0.35 & -0.56 & -0.210 \\
GW_Storage change & 1.59 & -1.50 & 0.086 \\
Land recharge & 1.10 & 0.14 & 1.237 \\
GW_Pumpage & -0.39 & -1.78 & -2.171 \\
Flow in (Boundary) & 0.20 & 0.20 & 0.400 \\
Flow out (Boundary) & 0.15 & 0.15 & 0.300 \\
From Aquifer 2 & 0.18 & 0.35 & 0.527 \\
\hline
\end{tabular}

\subsection{Impact of Climate Change on Flow Budget Pattern of Groundwater System and Conjunctive Use}

The impact from climate change was shown in Fig. 6 where the land recharge will decrease in the periods of both the near future and far future periods compared with the past due to the increase of evapotranspiration (temperature). The ratio of average recharge rate in near future and far future periods compared with the present is 0.42 , and 0.50 respectively. The heads of groundwater in the selected stations in the study area will be lower due to less land recharge as shown in Fig. 7 . The water table will decrease approximately $0.23,0.16$ $\mathrm{m} /$ year in near future and far future periods respectively.

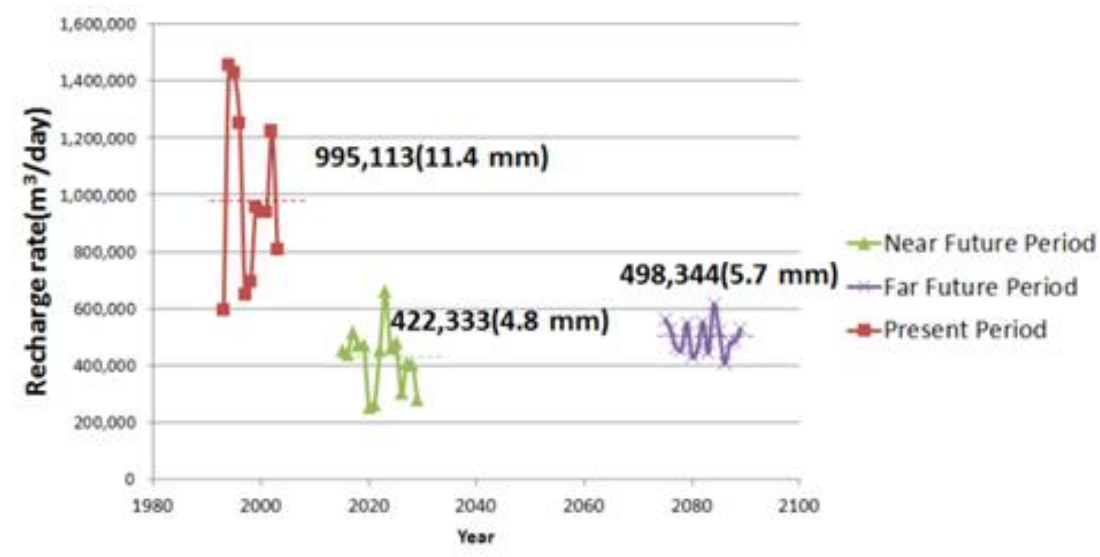

Fig. 6. The average groundwater recharge rate from projected future climate data. 


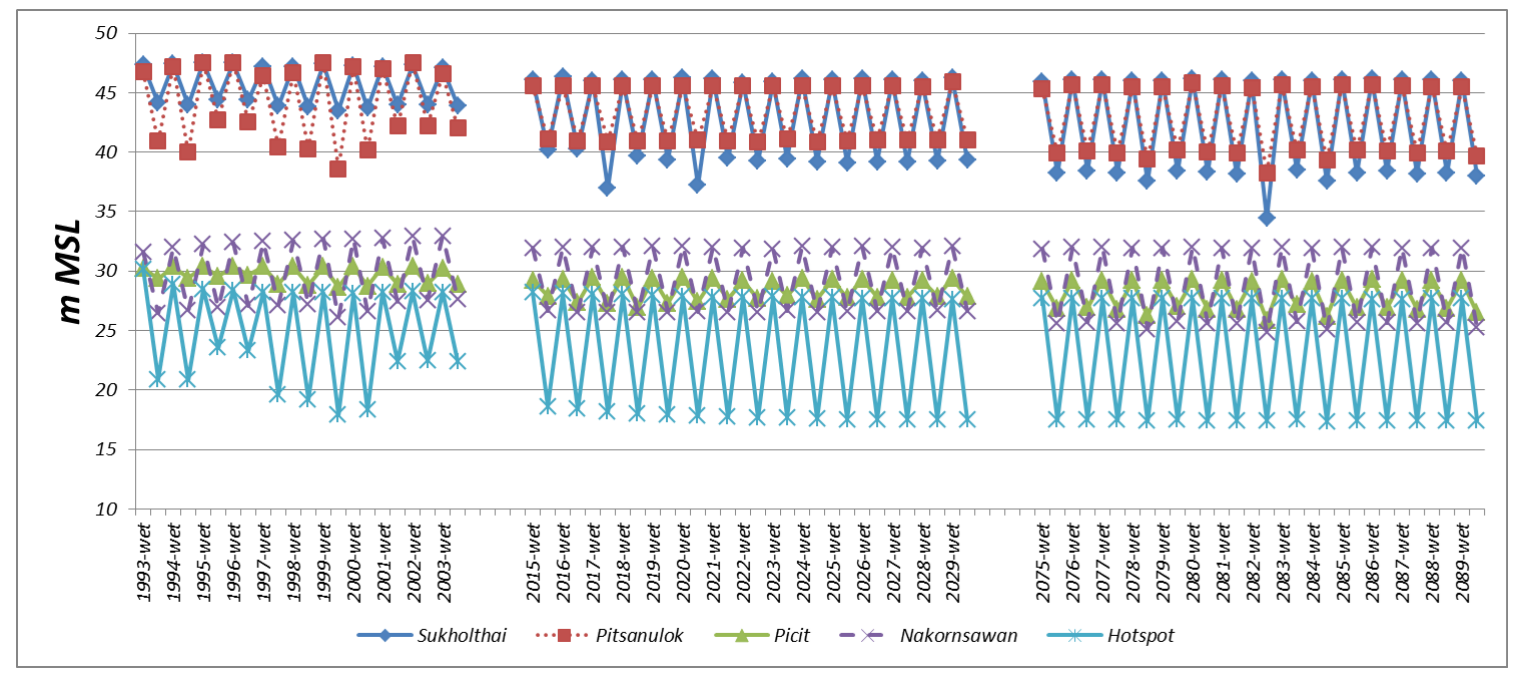

Fig. 7. The groundwater levels at selected locations.

From Fig. 8, the hot spot with seriously lower water level will occur in some areas of Uttraradit, Sukholthai, Phisanulok, Kampaengphet, Pichit and Nakhonsawan Provinces, especially in upper area of Plaichumpol Irrigation Project, the decrease of water level is up to $10 \mathrm{~m}$.
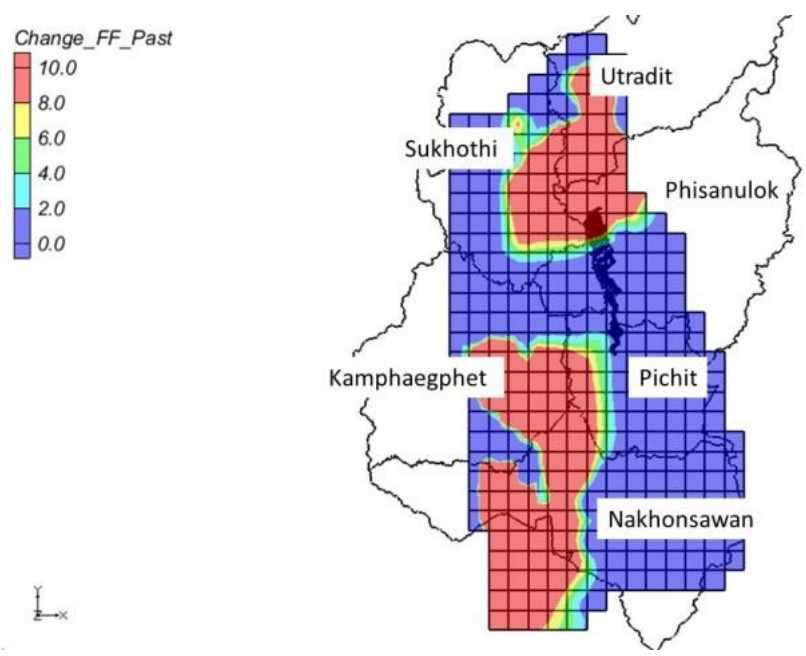

Fig. 8. The change of water level (in meter) in the aquifer by the end of far future period.

Table 3. The seasonal and annual flow budget change of groundwater system in the near future and far future periods.

\begin{tabular}{lrrrrrr}
\hline Time Period & \multicolumn{3}{c}{ Near Future (MCM) } & \multicolumn{3}{c}{ Far Future (MCM) } \\
\hline Season & wet & dry & annual & wet & dry & annual \\
\hline River recharge & 36.50 & -57.83 & -21.33 & 40.15 & -44.05 & -3.90 \\
GW_Storage change & 57.33 & -274.61 & -217.28 & 60.23 & -275.78 & -215.55 \\
Land recharge & 197.82 & 51.52 & 249.34 & 197.82 & 54.47 & 252.29 \\
GW_Pumpage & -147.53 & -355.45 & -502.98 & -135.32 & -364.27 & -499.59 \\
Flow in (Boundary) & 36.50 & 36.50 & 73.00 & 36.50 & 36.50 & 73.00 \\
Flow out & -27.38 & -27.38 & -54.76 & -27.38 & -27.38 & -54.76 \\
(Boundary) & -38.58 & 78.03 & 39.45 & -51.54 & 68.95 & 17.41 \\
From Aquifer 2 & & & & & &
\end{tabular}

Remark: “-” represents a decreasing value. 
The seasonal flow budget change of groundwater system in the near future and far future (in Table 3), impacted from the climate change condition, shows that the average groundwater pumpage will increase to $503 \mathrm{MCM}$ in near future and it will reduce to $500 \mathrm{MCM}$ in far future which slightly decreases from the near future. The annual river recharge will reduce to $-21 \mathrm{MCM}$ and $-4 \mathrm{MCM}$ in the near future and far future. For all of these results, the groundwater storage change will be -217 MCM and -215 MCM in near future and far future periods respectively. When focused in dry season, the river recharge will reduce to $-58 \mathrm{MCM}$ and -44 MCM which means that the groundwater recharged to the river will reduce in dry season and this will effect on the surface water storage in dry season.

The conjunctive use ratios in the future are demonstrated in Fig. 10 and the mean conjunctive use ratio in annual basis will increase in near future and far future to $18.5 \%$ and $16.3 \%$ respectively, which means that there will have more groundwater use due to more water shortage situations in the near future and far future.

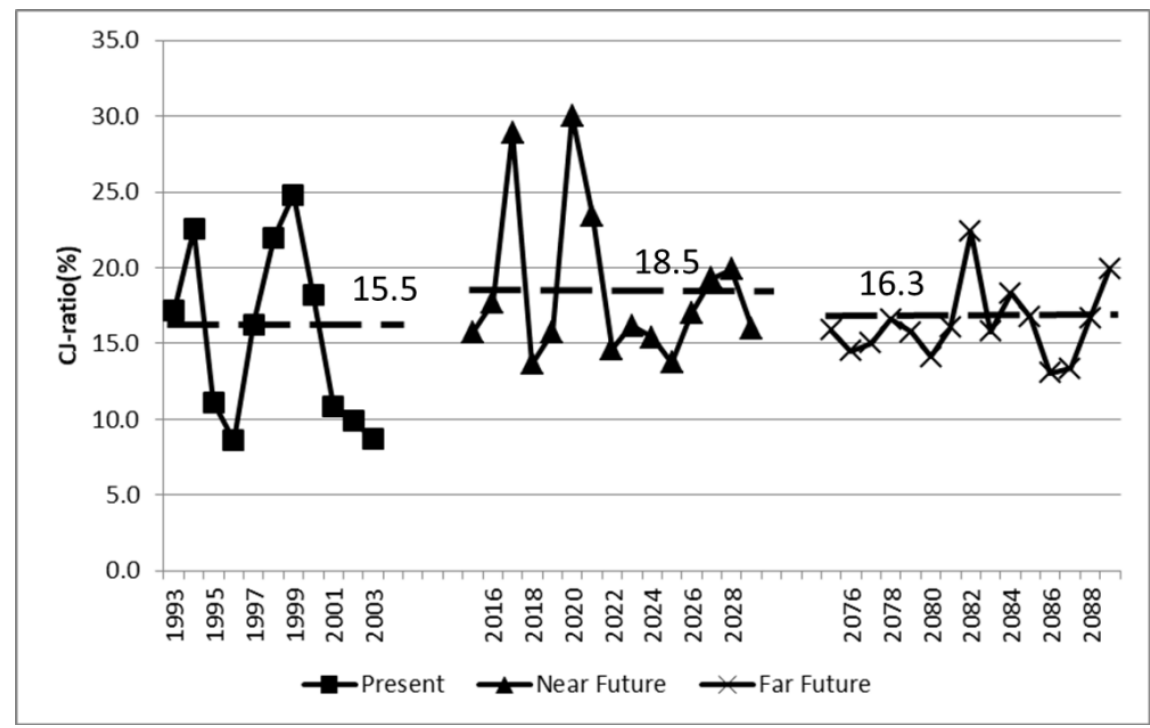

Fig. 10. The conjunctive use ratios in the present, near future and far future period.

\section{Conclusions and Recommendations}

For the flow budget of the groundwater system in Present period, the main input is from land recharge and the main outputs are river recharge and pumping. The average land recharges were 1.1, 0.137 and 1.237 $\mathrm{MCM} /$ season/day in wet season, dry season and annual basis respectively. The river recharge works differently from land recharge, i.e., it recharged to aquifer in wet season $(0.35 \mathrm{MCM} / \mathrm{season} /$ day $)$ but it received water from aquifer in dry season(-0.56 MCM/season/day). The amounts of $0.35,-0.56$ and -0.21 $\mathrm{MCM} /$ season/day were in wet season, dry season and annual basis respectively. The average groundwater pumpage was high nearly $1.8 \mathrm{MCM} /$ season/day in dry season, thus, the average groundwater storage change decreases to $1.5 \mathrm{MCM} /$ season/day in dry season. This was a reason that the average groundwater level in dry season in this area decreased. Groundwater is used in the dry year more than in the wet year. The sw-gw conjunctive use ratio was highest $(23-25 \%)$ in drought year and the lowest was in wet year $(9-11 \%)$.

The impact from climate change can be seen from the flow budget change of groundwater system in the near future and far future. The land recharge will be less due to higher temperature and more groundwater pumping needed due to higher irrigation demand which will induce more use of groundwater and lower groundwater level. The average groundwater pumpage will be $503 \mathrm{MCM}$ in near future and it will be 500 MCM in far future (or slightly decrease from the near future). The river annual recharge in annual basis will decrease to $-21 \mathrm{MCM}$ and $-4 \mathrm{MCM}$ in near future and far future. The groundwater storage change will decrease to $-217 \mathrm{MCM}$ and $-215 \mathrm{MCM}$ in near future and far future period, respectively. When focused in dry season, the river recharge will be $-58 \mathrm{MCM}$ and $-44 \mathrm{MCM}$ which means that less groundwater will be recharged to the river in dry season and this will have minus effect to surface water storage in dry season. The conjunctive use ratio in the future will increase in both near future and far future due to the increase in groundwater use. 


\section{References}

[1]. Chulalongkorn University, "The impact of climate change on irrigation systems and adaptation measures (Case Study: Plaichumphol Irrigation Project, Thailand)," presented at JIID Seminar on Impact of Climate Change on Irrigation Systems, Bangkok, Jan. 26th, 2010.

[2]. S. Koontanakulvong, "The study of conjunctive use of groundwater and surface water in Northern Chao Phraya Basin,” Final Report, Department of Groundwater Resources, Chulalongkorn University, 2006.

[3]. S. Koontanakulvong and W. Chaowiwat, "GCM data comparison and its application to water disaster adaptation measures in Thailand," Technical Report, Chulalongkorn University, March, 2011.

[4]. A. Krüger, U. Ulbrich, and P. Speth, "Groundwater recharge in Northrhine- Westfalia predicted by a statistical model for greenhouse gas scenarios," Physics and Chemistry of the Earth, Part B: Hydrology, Oceans and Atmosphere, vol. 26, no. 11, pp. 853-861, 2001.

[5]. V. P. Singh, Elementary Hydrology. Pearson College Division, 1992.

[6]. C. Suthidhummajit and S. Koontanakulvong, "Climate change impact on groundwater recharge in Upper Central Plain and Plaichumpol Irrigation Project, Thailand," 2015.

[7]. W. Bejranonda, S. Koontanakulvong, M. Koch, and C. Suthidhummajit, "Groundwater modeling for conjunctive use patterns investigation in the upper Central Plain of Thailand," in Aquifer Systems Management: Darcy's Legacy in a World of Impending Water Shortage. London, UK: Taylor \& Francis Group, pp. 161-174.

[8]. S. Koontanakulvong and C. Suthidhummajit, "The role of groundwater to mitigate the drought and as an adaptation to climate change in the Phitsanulok Irrigation Project, in the Nan Basin, Thailand," Jurnal Teknologi (Sciences \& Engineering), vol. 76, no.15, pp. 89-95, 2015. 